\title{
Bioethica
}

Vol 1, No 2 (2015)

Bioethica

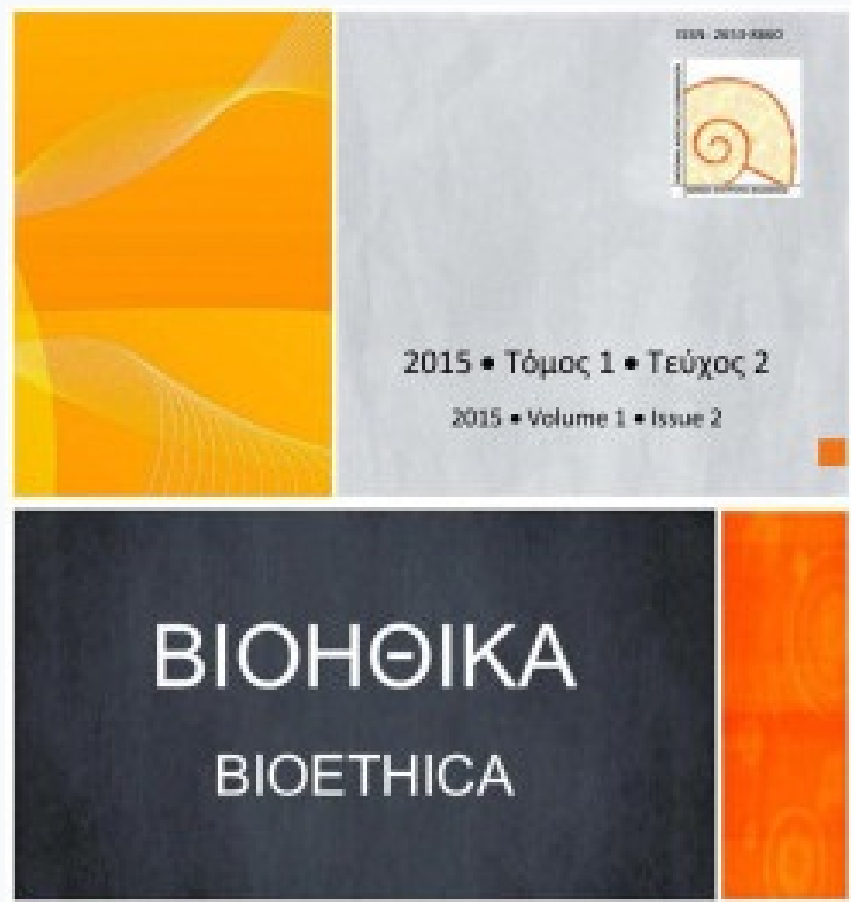

\section{Talent as an unintentional agent}

Konstantinos Papageorgiou (KWvotavtívos Папауєшрүíou)

doi: $10.12681 /$ bioeth. 19651

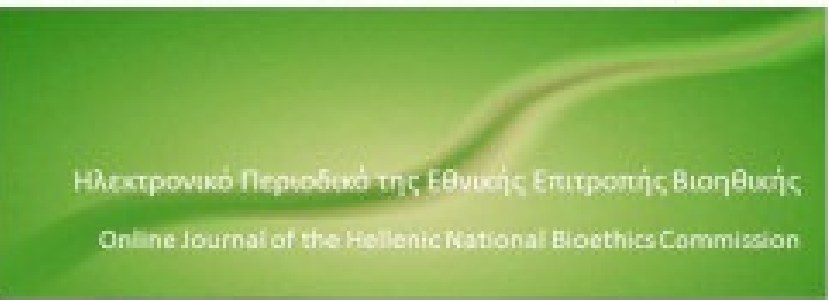

To cite this article:

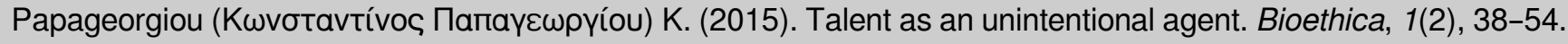
https://doi.org/10.12681/bioeth.19651 


\title{
Пршто́тuтฺn Eрүaбia
}

\section{Talent as an unintentional agent}

\author{
Konstantinos G. Papageorgiou, MSc
}

cconstantinoss@gmail.com

\section{Summary}

Unintentional exposure is a novel concept. No single person has coined the term. It mainly refers to substances and activities affecting individuals without their consent - be it informed or not. In the broader field of applied ethics in general, and of bioethics in particular, the scope of application extends from nutrition (GM, functional food), to pollution (chemical-, air-, light-, noise-, radioactive contamination etc.), climate change, embryo rights, drug side-effects (especially in regard to chemotherapy), radiation (e.g. food), Permissible Exposure Limits, education and (bio-)terrorism. In the discussion about talent and giftedness ${ }^{1}$ there are two main approaches or schools of thought. On one hand, talent is conceived as an exclusive agent, in that some individuals are born more capable than others. On the other hand, a different school of thought advocates the modification of body and mind of all individuals in order for them to achieve similar levels of high performance. In the first case, individuals are bound to their nature, while in the latter instance they are prisoners of their environment -two equivalent positions in terms of autonomy and freedom. The latter will be argued to be the case; as a result, a connection with unintentional exposure will be established.

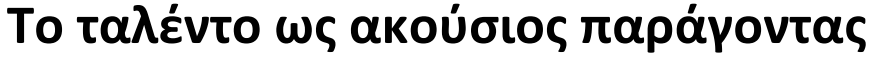

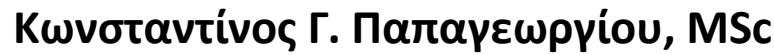

\section{Пєрí $\eta \psi \eta$}

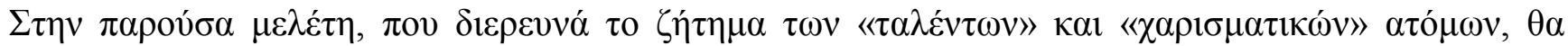

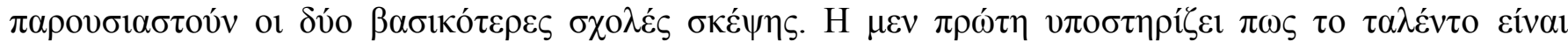

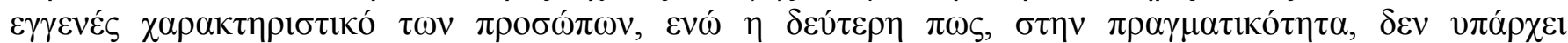

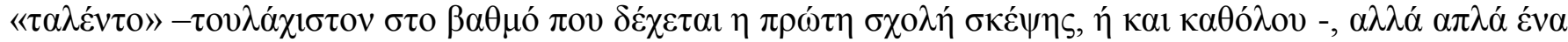

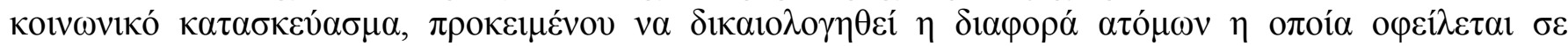

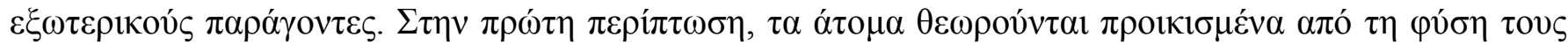

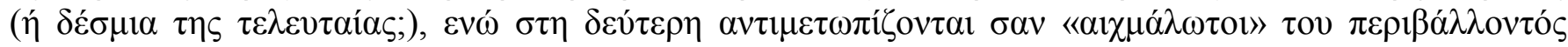

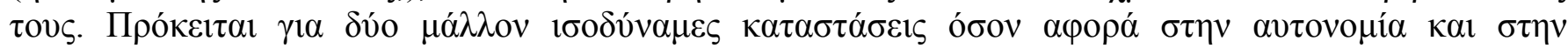

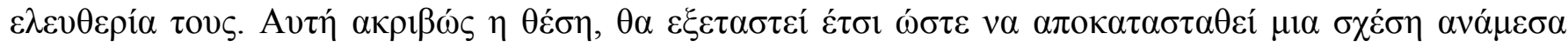

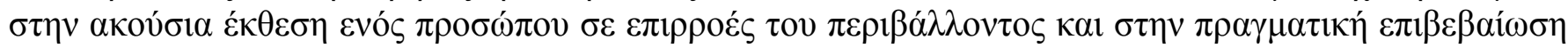

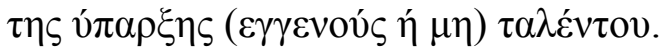

\footnotetext{
${ }^{1}$ In this context the terms "talent" and "giftedness" will be used interchangeably to signify the general state of being $a$ priori more capable in any skills, fields or expertise than a mean population.
} 


\section{Introduction}

The present article deals with talent in an unusual manner: talented individuals haven't chosen to be the carriers or hosts of any exceptional ability. Either because they were born with it or because their environment projected the idea of talent on them, they became the unintentional talent-operators. We may take it for granted even, that they are pleased with this "lottery ticket" - and not succumb under the burden of responsibility. Still, they remain exposed to talent, which, under this interpretation, becomes an unintentional, external agent.

The theoretical ramifications of the two cases, i.e., talent as an either internal or external agent, appear to be at least twofold. One could indeed observe we grow hair, teeth and nails (and unfortunately, tumors). Are we unintentionally exposed to these then as well? The whole debate of unintentional exposure and consumption is about external influences, not about our own inclinations and bodily functions. However, after analyzing the relevant terms, it will be shown both cases to be reducible to just one, namely to talent seen as an externally posed agent. From then on, the consequences for autonomy, freedom and rights will be discussed from a philosophical / epistemological perspective.

The discussion addressing the talent hypothesis (i.e. there is talent) is quite extensive. It is impossible here, within the confines of this article, to effectively expose the whole debate. For this reason, the reader is referred to the report the author has compiled for the National Bioethics Commission of Greece, by demand of the latter (Papageorgiou, 2014).

The discussion in regard to the talent debate may be analytically broken down to:

1. Theory, Definitions, Empirical evidence.

2. Findings.

2.1 Motor \& cognitive abilities.

2.2 Findings on jpf's.

3 . Gene studies.

4. Motivation.

5. Environmental effects.
6. Study of expertise.

7. Performance enhancing.

The former layout will be the guide towards describing the scenery in this arena of fierce debate.

\section{Theory, definitions and empirical evidence}

Null Hypothesis 1:

- Ability, gift (< giftEDNESS) and talent are three positive static abstract structural concepts, all constituting necessary conditions -i.e. a priori potentials, prerequisites, necessary causes, initial settings etc.- definable in some appropriate imagined or conventionally decided biological, psychological, social, cultural and environmental contexts -also aptitude, capability, capacity and any other term to an analogous semantic effect in common current language. In the singular grammatical number, these three concepts are progressively less abstract and more concrete / structural, descending from supersets towards subsets. When put in the plural grammatical number, these settheoretical domains undergo partitions. Capacity and giftedness are two judgmental assessments of the above. AbilitIES, giftS and talentS then become partitioned subsets of trainable "special" capacities contingent on control. From abilities, given the next two predicates, expertise arises.

How is superior performance achieved? One may call the phenomenon of exceptionally skilled individuals the explanandum. The explanation could be either talent, proper practice (e.g. deliberate practiceK. A. Ericsson, Krampe, \& Tesch-Römer, 1993), both of them or neither of them. The nature vs. nurture debate is still raging.

Accepting talent as an inherent factor already has serious ethical and methodological complications. The talent hypothesis is based 
on observations of highly skilled performers. But are we entitled to argue in favor of the talent hypothesis based on a posteriori observations of performance? Or is this just another expression of magical thinking? (Helgadóttir, Menzies, \& Einstein, 2012; Papageorgiou, 2010; cf. pygmalion effect Rhem, 1999; Wilson, 1984). Before elaborating further on the matter, one should present relevant definitions. Apart from a "commodity that sells well (...) at least in the Western world" (Dai, 2009, p. 38), what other definitions about talent can be found in the literature?

There are two crucial concepts amidst the talent debate: talent and giftedness, which will be used in this paper interchangeably.

- "Talent designates the outstanding mastery of systematically developed competencies (knowledge and skills) in at least one field of human activity to a degree that places an individual at least among the top $10 \%$ of "learning peers" (all those who have accumulated a similar amount of learning time from either current or past training)".

- "Giftedness designates the possession and use of untrained and spontaneously expressed outstanding natural abilities or aptitudes (called gifts), in at least one ability domain, to a degree that places an individual at least among the top $10 \%$ of age peers"(Gagne, 2009, pp. 157-158).

- "[A] prodigy is a child who, before the age of 10 years, displays extraordinary intellectual-creative performance and/or achievements in any type of a real activity (...). The difference between 'prodigy' and 'the very gifted' consists mainly in the age boundary (i.e. 10 years)" (Shavinina, 2009, p. 233).

The former definitions are suffering from basic epistemologic defects. For example, they consider a phenomenon through its appearance (telic cause) and not by its necessary causes; in other words they define a notion describing as substantial characteristics the phenomenon itself (the outcome) and not its pre-existing causes. Talent or giftedness may rather be defined as the causes of outcomes. Moreover, according to van Rossum and Pfeiffer, there is no consensus in regard to the validity of the distinction between talents and gifted individuals both in theory and in practice (Pfeiffer, 2009; Rossum, 2009, p. 758).

The term talented may be used both descriptively and explanatory. In the former sense, in order to describe someone as a great performer or, in the latter case, to explain the very reason some individual came to become a great performer (Dai, 2009, p. 40). Gagne arguably presumes the same, as, according to him, one may be talented in that he/she demonstrates an outstanding mastery, or one may be talented owing to belonging to a statistical elite (10\% of population). Indeed, being gifted or talented by virtue of surpassing the $90 \%$ of one's peers seems legitimate; a remaining question is whether these performance differences are normally distributed, or else, if there is a gap between the talented (or gifted) and the rest. Indeed there is a continuum. One may not treat points from a continuum as though elements of a set based on a priori observation. It is purely a matter of convention which part of the continuum one chooses to extract and include in the set, and it is highly questionable how effectively this extraction can in fact be carried out.

But what part of the so-called talent hypothesis is of interest? As in Turing machines, what is important is the product and not the way it may be realized ${ }^{1}$ - and a definite product can be realized from considerably different Turing machines where $\{$ Cause $\} \subseteq\{$ Result $\}$, which is isomorphic to (Cause $\rightarrow$ Result). By this approach, the study of talent is indeed the study of expertise seen from the machine's perspective, that is, the human machine. Whatever talent is, the author argues, is not of particular interest to society despite the claims to the contrary. What makes a difference continues to be the outcome (expertise), and talent by itself, perceived as $a$

\footnotetext{
${ }^{1}$ Multiple realization is a basic characteristic of Turing machines.
} 
priori potential, is merely of academic importance.

In general, theories of ability or intelligence that espouse the existence of definite innate traits are called entity or fixed theories, against the incremental or malleable theories that adopt an open view on the people's ability to change over time (Rattan, Good, \& Dweck, 2012).

\section{Findings}

\subsection{Motor and cognitive abilities: findings in elite individuals}

Abilities, either cognitive or physical, are the simplest analytical elements of skills. For a list of abilities related to motor skills one is referred to Schmidt \& Wrisberg, 2008, p. 169 , and for abilities such as the mathematical ability to Geake, 2009, p. 268. Notions discussed here (such as expertise, talent etc.) are intelligible because people perceive behavior reducible to such abilities. However, if abilities do exist, are they measurable? Do they have a genetic component? Can these abilities be somehow incorporated in the general model of talent? The question about talent and giftedness becomes increasingly more specific.

\section{Motor skills}

A list of abilities includes all kinds of strength and movement abilities, spatial and temporal abilities, perceptual abilities etc. Whereas they are easyy to assess as they can be directly measured, their predictive value is low and as Schmidt \& Wrisberg explain: "it appears that predicting future performance on the basis of people's abilities alone is, at best, an imperfect science" (Schmidt \& Wrisberg, 2008, p. 182). The inability to predict future expertise based on talent is also stressed by Howe et al. and Durand-Bush \& Salmela (Durand-Bush \& Salmela, 2001, p. 284; Howe, W., \& Sloboda, 1998). Characteristically, the talent identification program of the Australian Institute of Sport has been criticized for its exclusive character and its effectiveness (Anshel \& Lidor, 2012; Rossum, 2009, pp.
780-781). As Howe points, "talent" is a descriptive notion and not a predictive or explanatory notion, a confusion existing even among scientists (Howe et al., 1998, p. 400). In other words, talent is the containing set, not the contained subset, because it resides in a higher level of abstraction.

\section{Cognitive abilities}

Discussing abilities, Intelligence Quotient is undoubtedly one of the most popular and well-researched measures of general cognitive abilities. Supposedly, it measures $g$ which stands for ' $\mathrm{g}$ 'eneral cognitive abilities and is a broad measure of the intellectual capacity of individuals, as Charles Spearman proposed. However, researchers such as Sternberg find the $g$ model rather reductionistic (Sternberg, 2002). IQ is just a statistical entity, not an inherent human capacity. By definition, it does not correspond to a real measure, such as height, but signifies a relation between individuals on a test; the test itself is in written form. It does not measure a specific entity or function but rather performance on a piece ofpaper. Intelligence is not a biological procedure; it is a conception of interpreted perceptions of various epiphenomena emerging from a series of biological procedures, which (the procedures), in any case, have not been neither well- nor fully-described; indeed we do have some correlations (see studies of Haier cited), but again, correlation does not imply causation ${ }^{2}$. How could one measure the epiphenomenon and directly draw conclusions about the biological procedure, as if IQ and brain processes identified? IQ could be conceived as a convenient convention to grossly compare individuals. However, as Flynn and others have argued, IQ measurements are inconsistent and one-sided (cf. flynn effect Flynn, 1984; cf. emotional intelligence Goleman, 1995;

\footnotetext{
2 This is another classic example of the fallacies of scientia since it deviated from episteme: its inability to operate in complete abstraction. The result here is that it tries to force the system to produce its own input, the input being a working hypothesis, i.e. intelligence. Intelligence is the containing set, not the content to be hunt for.
} 
William T. Dickens, James R. Flynn, Curtis Crawford, Mary Alice Fisher, Robin Hanson, 2001).

The normal distribution of IQ is shown in figure 1. The interpretation of the Gaussian bell-curve to the distribution of natural ability was first proposed by Francis Galton in Hereditary Genius (Galton, 1869), who himself, according to modern measurements, had an estimated IQ score of 200 , in relation to his less gifted (in terms of IQ) cousin Charles Darwin. Darwin was found to have an IQ of around 135 (D. Simonton, 1999, p. 110). In Table 1, IQ prevalence is presented for general population.

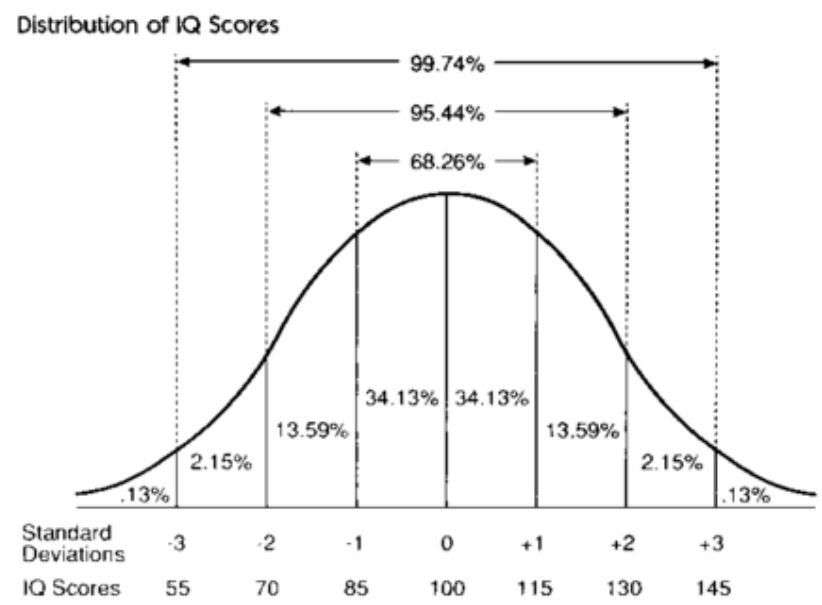

Figure 1. IQ distribution (Locurto, 1991, p. 5).

\begin{tabular}{lll}
\hline Level & IQ range & Prevalence \\
\hline $\begin{array}{l}\text { Mildly (or } \\
\text { basically) } \\
\text { gifted }\end{array}$ & $115-129$ & $1: 6-1: 40$ \\
$\begin{array}{c}\text { Moderately } \\
\text { gifted }\end{array}$ & $130-144$ & $1: 40-1: 1,000$ \\
$\begin{array}{l}\text { Highly gifted } \\
\begin{array}{c}\text { Exceptionally } \\
\text { gifted }\end{array}\end{array}$ & $145-159$ & $1: 1,000-1: 10,000$ \\
$\begin{array}{l}\text { Profoundly } \\
\text { gifted }\end{array}$ & $160-179$ & $\begin{array}{l}1: 10,000-1: 1 \\
\text { million }\end{array}$ \\
\hline
\end{tabular}

Table 1. IQ prevalence (Gross, 2009, p. 337).

By default, IQ scores say something about the past, i.e. how individuals did in relation to each other in a given test. IQ studies include Lewis Terman's classic study of a large pool of individuals, and the Study of Mathematically Precocious Youth (by means of SAT scores) (Davis, 2009, p. 1036; Lubinski, Benbow, Webb, \& Bleske-Reckek, 2006; Terman M. Lewis, 1926, p. 30). Terman's study has been criticized for excluding individuals such as William Shockley (a Nobel laureate) and for the actual success of the studied individuals when put on a per capita basis: "Hence, Terman's intellectual elite was not of the same caliber as the true scientific elite of the same nation and era" (D. K. Simonton, 1994, p. 222).

IQ was not designed to, nor can it measure brain processes. IQ is measured through a standardized test that reveals the relative performance of individuals. IQ makes no direct biological or cognitive measurement. Moreover, IQ curves have another inherent problem if taken "literally". Simonton notes that according to the year $2000^{\text {th }}$ 's population, more than half a million intellects would exist with IQ's 340 or higher (D. Simonton, 1999, p. 151)!

That said, there have been many research findings that highly correlate ${ }^{3}$ IQ scores (whatever IQ score might signify) to various brain functions, academic or other achievements and outcomes. For example, Haier et al. have found a significant correlation between high IQ scores and differences in brain morphology: more gray matter is associated with higher IQ in discrete Brodmann areas (BA) including frontal (BA 10, 46, 9), temporal (BA 21, 37, 22, 42), parietal (BA 43 and 3), and occipital (BA 19) lobes and near BA 39 for white matter (R. J. Haier, Jung, Yeo, Head, \& Alkire, 2004). Brodmann areas that correlate with IQ tests are presented in Figure 2 (R. Haier, 2009, p. 30).

More recently, Brant et al. summarize the current status of IQ: "IQ predicts many measures of life success, as well as trajectories of brain development. Prolonged cortical thickening observed in individuals with high IQ might reflect an extended period of synaptogenesis and high environmental sensitivity or plasticity" (Brant et al., 2013).

However, one should not forget that whether IQ is an effective measure of future

\footnotetext{
${ }^{3}$ Again, correlation does not imply causation.
} 
accomplishments or not, whatever it might signify, violating or not cause-effect relation, what is important in the talent debate is another question: are IQ scores genetically pre-determined? If so, can one intervene and change them?

\section{Physical domain}

Regarding physical characteristics, Klissouras's studies of monozygous twins are classic (V Klissouras et al., 2001; Vasilis Klissouras, 1971). His findings are in favor of the existence of traits; however, the ecological validity of his studies is open to discussion.

Other studies address respiratory capacity. From The HERITAGE Study's perspective, Bouchard et al. conclude that "the trainability of $\mathrm{VO}(2 \mathrm{max})$ is highly familial and includes a significant genetic component". Ericsson strongly objects regarding the validity of these findings for elite populations (Ericsson, 2007). The same debate includes discussions about the principle of individuality ( $c f$. non-responders) stating that not all individuals have the same capacity to adapt to exercise training (Wilmore \& Costill, 2004, p. 20). Wilmore \& Costil imply that the HERITAGE findings are generilizable to other parameters, without providing any further support for their argument (p.20).

\subsection{Findings on JPF's}

If talent exists, in an a priori exclusive way, then it would not be possible for Just Plain Folks (JPF's) to attain world-class performance. Is that the case?

On behalf of JPF's, there is a considerable literature presenting achievements and underlying mechanisms which in some way enable JPF's to "become talented", i.e. high achievers. Ericsson et al. mention cases of such improvements: after hundreds of hours of practicing memorization of digit-lists, student's memories increased from a typical 8 digit, to over 80 digits-an over 70 standard deviation improvement; these individuals possibly do not even have any structural brain differences or intellectual ability compared with other JPF's or world's top memorizers, as a spatial-learning strategy is used by all (Ericsson, Nandagopal, \& Roring, 2009b, p. 200; Maguire, Valentine, Wilding, \& Kapur, 2002, p. 90). The most prodigious mental calculator in the world, Shakuntala Devi, has been found to have sustained "enormous and prolonged interest and practice in a particular skill [which] probably plays a larger part in extremely exceptional performance than does psychometric $g$ or the speed of elementary information processes" (Jensen, 1990). "All of the most outstanding mental calculators (...) spent many years practicing before achieving superior performance" (Ericsson \& Kintsch, 1995, p. 50). Chao $\mathrm{Lu}$, the Guinness world record holder for reciting 67,890 digits of $\pi$ in 24 hours and 4 seconds, based his achievement in many traditional memorizing techniques which he improved; Lu's achievement was based on his "consistent engagement in thousands of hours of memorization" ( $\mathrm{Hu}$, Ericsson, Yang, \& Lu, 2009). They also found that $\mathrm{Lu}$ exhibited a memory digit-span within the normal range - in contrast to other memorists who have extended digit-spans of over 15 digits.

Not only do mental strategies lead to adaptations resulting in impressive achievements, but also physical adaptations may enable high school and college students to dramatically increase the average of 20 pushups they are capable of; Ericsson et al. refer to adults who have been able to complete over 6.000 push-ups after special training; the current record is 46.001 push-ups in just over 22 hours by the 43. y.o. Charles Servizio in 1993 (Ericsson et al., 2009b, p. 201; Wikipedia, n.d.).

Contemporary amateur athletes outperform past gold records (Ericsson, 2006, p. 690). The sub-4 minutes (3.59) mile run of the Olympic athlete, Sir Roger Bannister, in 1954 is an achievement that isn't likely to make it to the local news nowadays (current record being at $3.43 \mathrm{~min}$.$) , let alone grant$ someone the title of "Sir". Likewise, in the USA official diving website one finds the phrase: "While a double somersault from the platform was considered dangerous in 1904, 
today's divers are completing flawless reverse four and a half somersaults with ease" (O'Brien, n.d.). As it would be doubtful to conclude that within just 100 years the human body evolved, one may be sceptical as to what exactly "talent", "achievement" and "expertise" represent, other than a social convention, a value judgment.

In sciences the same seems to apply. Roger Bacon argued that it would be impossible to master mathematics in less than 30 to 40 years (Ericsson, 2006, p. 690). Contemporary musicians (piano and violin experts) master music which considered "unplayable" by the best musicians in the $19^{\text {th }}$ century. Modern expert chess players (1990 world championship) have improved in skill by 3 to 4 standard deviations since 1890 (Ericsson, Nandagopal, \& Roring, 2009a, p. $135)$.

\section{3 "Gene Hunting"}

On a more basic level, can the DNAsequencing techniques reveal genetic influences on talent?

"Genes are the essence of life: they carry the coded messages that are stored in every living cell, telling it how to function and multiply and when to do so" (italics from the original). The aforementioned statement comes from the first words of the Report of the Commission on the Ethics of Gene Therapy, as was Presented to Parliament by Command of Her Majest [in] January 1992 (sic). Such statements reflect general public's view as well. Is such a view legitimate though?

"Few discoveries would have greater impact than identifying some of the genes responsible for the heritability of cognitive abilities" (Plomin \& Haworth, 2013, p. 562). Gene hunting refers exactly to that aspiration. However, efforts and hopes towards these directions have been largely unsuccessful: "the molecular genetics of psychology and social science requires approaches that go beyond the examination of candidate genes" (Chabris et al., 2012). This is of course another result of the confusion between analytic the abstractive methods, since it is attempted to reduce an abstract component (intelligence) to an analytic one (genes); in other words, establishing such a causal relation from observations alone (and not as a hypothesis) is invalid.

Atlan explains the way a global misunderstanding occurred in how are genes perceived as analogues of computer programs: one of the most eminent biologists of the last century, Ernst Mayr, is responsible for the success of the term "genetic program" which was accepted uncritically and even semantically altered in relations to Mayr's original thoughts (Atlan, 1999, p. 35).

Information seems to exist both in the structure of genes, in their energy print and within the cytoplasm: the whole organism dictates the activation of genes, and the structure of genes is not the central executive system (Atlan, 1999, p. 58; Kono, 1997, p. 74). The surprisingly similar genome with vastly different species, such as drosophila and mice, further supports this view (Atlan, 1999, p. 59). "DNA is not selfreproducing; second, it makes nothing; and third, organisms are not determined by it. (...) DNA is a dead molecule, among the most nonreactive, chemically inert molecules in the living world (R Lewontin, 2001, p. 142). In regard to IQ, Lewontin argues: "The genes for IQ have never been found. Ironically, at the same time that genetics has ceased to be a popular explanation for human intellectual and temperamental differences, genetic theories for the causation of virtually every physical disorder have become the mode. 'DNA' has replaced 'IQ' as the abbreviation of social import. (...) The failure to find such genes continues and it seems likely that the search for the genes causing most common diseases will go the way of the search for the genes for IQ (Richard Lewontin, 2011).

Another clue comes from computer science: when tested in a computer, the "learning to learn" explanation was successful in advocating the capacity to reach expertise by expanding learning capacity via just learning more (Butko \& Movellan, 2007).

Geake insists that "gifted kids cannot help being gifted" on the base of structural 
neural differences, mainly citing among others Haier et al. to support the physical substrate for this difference (Geake, 2009, p. 271; R. J. Haier et al., 2004). This viewpoint has two problems. Firstly, the author of the present article supports that individuals (even young children), may be vastly different in relation to each other for reasons either unknown or related to the effort of the individuals or the effects of their environment (discussed later as well). The term "gift" however implies some exclusive superiority that stems outside the individual, from someone/something (God? Nature?) that has favoured only certain individuals a priori. Secondly, Haier et al. 2004 have used individuals with a mean age of 27 years (R. J. Haier et al., 2004, p. 426). That can hardly say anything about the a priori condition of a human that comes into existence.

How could talent (a property) be brought about by analytical elements (genes)? The analytic and the abstractive method, complementary as they may be, follow completely different routes (Lekkas, 2003). Analytic-synthetic method starts by frittering a system into its constituents, and abstractivestructural method's first step is to subtract properties and include the system to broader supersets. Since structure and synthesis are parts of different methods, one should be careful not to use them interchangeably since they follow opposing routes.

\section{Motivation}

\section{Null Hypothesis 2:}

Motivation is a positive singular-number static abstract-structural concept, constituting a necessary and sufficient and strongly poetic condition-i.e. a subjective combination of $a$ priori potentials, prerequisites, necessary causes, initial settings etc. and a posteriori developments, methodologies, poetic causes, courses, aspirations, ambitions, identities etc.definable in some appropriate imagined or conventionally decided psychological, social, cultural and environmental contexts.

Skills do not lead to expertise; motivation does. There is no reason to believe that any healthy individual that engages in proper educational or training activity is going to be unable to improve his/her skills. One will appear to be incompetent to even attain college-level performance in a domain where he/she lacks motivation. Skills are not selfexistent and do not "grow" by themselves; they are rather situated and need the active commitment of individuals to find the relative (re)sources and develop their skills.

Van Rossum presents findings from various researchers that there is no such thing as "athletic personality", even when there seems to be some common psychological characteristics of many successful athletes, like self-confidence and achievement motivation (Rossum, 2009, p. 763).

"Talents are channeled by interests" (Hunt, 2006, p. 33). Indeed an enduring factor influencing performance is motivation. Ericsson et al. identify "zeal" as a component that might even have a hereditary component, but as discussed earlier here, it is too restrictive to view motivation as a fixed component (Ericsson et al., 1993, p. 364). Similarly, high school students who excelled in math, or pursued them to a higher level, were more intrinsically motivated, already from an earlier age; motivation contributes to academic outcomes independently of both intelligence and achievement (Gottfried \& Gottfried, 2009, p. 620). Which of the two factors lead to the other, motivation to success, or success to motivation?

As a matter of fact, motivational effects, heredity apart, can be viewed both ways. At one hand, motivation, as discussed in the previous paragraphs, may lead to excellence. Perceived excellence on behalf of the environment, on the other hand, may motivate the individual to actually excel (a selffulfilling prophecy), or even lead to the attainment of excellence itself, through the flow state the performer experiences, which increases motivation (Csikszentmihalyi, 1990; Ericsson et al., 2009a, p. 129). 
Motivation, and in specific, intrinsic motivation $^{4}$ due to its relation with success, may even be granted predictive properties (Sekowski, Siekanska, \& Klinkosz, 2009, p. 478). On one hand, practice is the most important aspect of improvement (Cote et al. 2007 p.190) and on the other hand motivation is the most important aspect for an individual to engage and continue practicing (Cote, Baker, \& Abernathy, 2007, p. 190; Ericsson et al., 2009a, p. 135). Furthermore, achievement motivation specifically, has been found to be a predictive factor in tennis (Ericsson, 2006, p. 693; Rossum, 2009, p. 780).

"Gifted" children are more motivated, and exhibit greater curiosity and mastery motivation than their comparison groups; moreover it is important to discriminate between intelligence and motivation, as motivation has been repeatedly shown to predict achievement independently of IQ (Gottfried \& Gottfried, 2009, pp. 619-620).

\section{Specific Environmental Effects}

There is a number of talent-related environmental effects. These effects may not have the strength to disprove the exclusivity of hereditary origins of high performance (i.e. "talent"), but certainly underline the influence of external parameters. These effects are known as the birth date and birth order effects, family \& nurture effect, ethnic and professional marginality effects, the orphanhood effect-and even more (e.g. D. K. Simonton, 2000, p. 316).

Indicatively:

- $\quad$ The relative age effect, accounts for the improved performance (and hence perceived talent) of individuals in activities (sports and school) where children are classified into categories, groups or classes, according to age criteria (Ericsson et al., 2009a, p. 143). The oldest children in relation to their youngest teammates or classmates may be almost a

\footnotetext{
4 "Intrinsic" is a term much more vague than expected, and bound to implicit conventions made. It is not clear at all where exactly are these boundaries between "internal" and "external".
}

year older. Then, older children are selected in various talent groups having access to better quality training and education.

- $\quad$ Birth order effect: Galton noted: "It is clear that the eldest sons do not succeed as judges half as well as the cadets" (Galton, 1869 , p. 88). Simonton proposes a number of explanations: firstborns are prone to identify with authoritory figures, whereas their younger siblings are more open to revolutionary ideas (D. Simonton, 1999, p. 135).

- $\quad$ The birth-place effect: Already Galton, in his remarkable book Hereditary Genius attributes a great deal of classical Athens's success to its population $(90,000$ free citizens) and diversity (40,000 resident aliens, almost half a million slaves) (Galton, 1869, p. 341). It seems that individuals coming from medium sized towns (population between 50,00099,000 ) have access to a vast array of resources with potentially more relaxed lifestyles, better human relationships and less aggressive competition in the beginning of their performing careers (Big Fish Little Pond effect) to benefit from and pursue their endeavors (Cote et al., 2007, pp. 194-195; Fraser-Thomas, 2010, p. 7).

\section{Study of expertise}

In the field of Science of Exceptional Achievement (Ericsson et al., 2009b) a series of concepts have been presented. Deliberate practice and career trajectories are such instances.

The core assumption of DP is that “... expert performance is acquired gradually and (...) effective improvement of performance requires the opportunity to find suitable training tasks that the performer can master sequentially - typically the design of training tasks and monitoring of the attained performance is done by a teacher or a coach"(Ericsson, 2006).

Deliberate practice has been found to be beneficial to all ages and levels, towards 
attaining expertise (Ericsson, 2007).

Yet another line of research provides significant insights in regard to the debate. A common perception of the public and experts of various disciplines about talents, is that talented, gifted, prodigious and genius people, as such, would of course need to practice, but are capable of great leaps: become virtuosi almost automatically, conceive already from early ages a pioneering idea "out of the blue" mainly thanks to their (pre-established) special cognition, and solve complex mathematical problems intuitively, even before accumulating any significant amount of practice - therefore justifying exactly their $a$ priori superiority.

Through a sociocultural evolution which usually erases mishits, one tends to idolize historic creators as individuals with all hits and no misses, considering them epic figures generating one Magnus Opus after another (D. Simonton, 1999, p. 157). However this is hardly ever the case, with geniuses making one blunder after another; Simonton mentions the "erroneous interpretations and even silly conjectures" Darwin was capable of publishing, the very role-model of many (even contemporary) scientists (D. Simonton, 1999, p. 157). Research shows that individuals who reach an elite level of performance do not begin their career with any advantage, nor do they progress differently with sudden increases in performance, but rather their improvement is gradual and time consuming. Ten years are stated as a prerequisite for attaining international level of performance; however the number of years may vary, according to Ericsson, from far less (500-1000 hours of practice requiring only 1-2 years for memorizing digits at world level) to far more an estimated 25.000 hours attainable only after 15-20 years of practice for winners in top international piano competitions (Ericsson, 2012, p. 2).

Simonton has elaborated a mathematical model which is based on Darwinian premises: conceptual variations that survive selection from individual self-criticizing to peer reviewing etc. Sufficiently developed concepts finally become products (Simonton 1999 p.161). Figure 2 shows Simonton's career trajectory model.

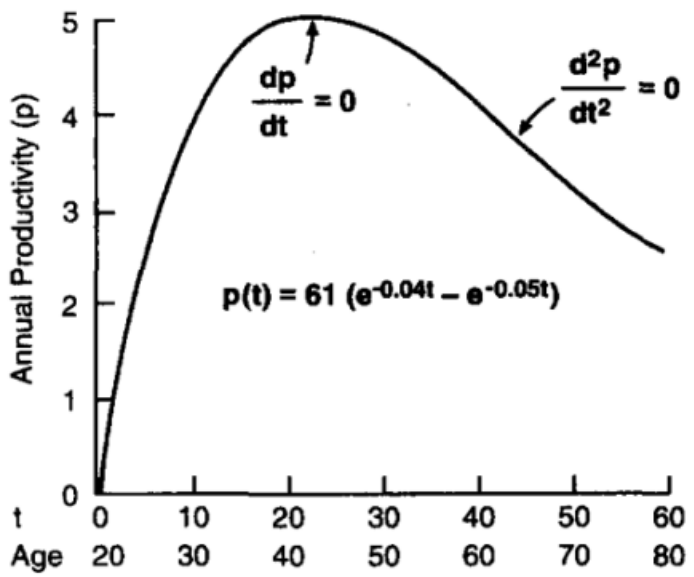

Figure 2. Productivity curve (D. K. Simonton, 1997, p. 69).

Some conclusions may be drawn that have a certain predictive value as well:(from D. K. Simonton, 1997):

- Quality and quantity are closely related (p.76).

- Quantity is an enduring characteristic of individuals (p.81).

- Half life, is "the career age at which $50 \%$ of the initial creative potential already has been transformed into either works in progress or completed contributions". According to the model, half-life is 15.4 years for poets, 21.7.for mathematicians, 20.4 for novelists, 28.9 for geologists, and 39.7 for historians. Therefore, poets may die younger leaving more work behind them (they "burn out fast"), in contrast to, say, historians (p.81).

\section{Enhancing Performance}

In this work, the study of talent is equivalent to the study of the expert. Becoming a talent is therefore the long process of attaining expert skills. Becoming a talent refers to the efforts to bypass nature by artificially enhancing performance -both physical and cognitive.

The debate on doping is fierce. Even motor skills may be enhanced by drugs, e.g. $\beta$ blockers improve accuracy in shooting types 
of sports (Wilmore \& Costill, 2004, p. 480). Gene doping, in order to modulate gene expression, is also prohibited (WADA, n.d.) Even though IQ pills are still a scenario of the future, a $20 \%$ of 1,427 scientists who were asked by Nature in 2008 responded that they "already use prescription drugs to enhance 'concentration' rather than for treating a medical condition" and that they were "willing to risk mild side effects to "boost their brainpower' by taking cognition-enhancing drugs" (R. Haier, 2009, p. 30). This is not particularly shocking, as it is already known that a growing body of healthy pupils, students and researchers abuse ADHD drugs ("study drugs") to endure hard studying days ("Adderall days") intellectually and emotionally (Vrecko, 2013, pp. 4 \& 10-11).

So, is it legitimate to wonder in what way is exceptional performance attained nowadays by people who are otherwise widely accepted and respected?

\section{Conclusions about talent}

In light of the above, "talent" is very far from the magical and automatic process of becoming virtuoso on your own before even anyone notices: too many notice and participate as well. Given the long process and difficulty in actualizing the "talent" potential, it is no wonder that expertise cannot be predicted by early "talent" indicators-or by their absence.

In both athletic and cognitive domains there is no single predictor (Rossum, 2009, p. 764) Talent cannot be considered as a unique determinant of high performance. This is in line with van Rossum's concluding remark that "Being labelled 'talented' is thus not a prerequisite for becoming a successful athlete" (Rossum, 2009, p. 767) -while, of course, it could still be the case that being labelled "talented" could still be important ( $c f$. selffulfilling prophecies). The same appears to be the case for cognitive domains, according to Wallace \& Maker who prefer to stress the potential of adequate teaching rather than student's abilities per se (Wallace \& Maker, 2009, p. 1114). Carol Dweck \& Ellen L.
Legget, are more to the point: "Intelligence is not a fixed commodity given at birth: with appropriate teaching and mentoring, all pupils can become better thinkers" (Dweck \& Leggett, 1988, p. 256).

The cause for the superior performance of JPF's could be talent-related, non-talentrelated, not-non-talent-related or any other combination. Observations alone are not a firm ground for articulating proper standards. There are good "proofs" for every conceivable hypothesis, so expecting to find the cause from the effects is, again, highly problematic.

All in all, talent is a value judgment on skills and abilities claiming observable and measurable applicability as an actual concept. Talent is an a priori potential or double a priori (or a meta-value judgement). Talent has not been proved; nor will it ever be: talent is a property, not an analytical component. Whoever tries to prove the existence of an abstract property confuses analytic with abstract methodologies. That is not to say that talent does not exist; it exists under specific conditions, namely the agreed definitions and hypotheses. Whoever tries to measure talent by constructing a metric based on. measuring talent commits an epistemological crime; she has confused metrēsis with metrike $\bar{e}^{5}$.

But just suppose for a moment that talent existed as an entity beyond doubt. Then consider two equally talented and motivated identical twins (supposing we could precisely measure both talent and motivation). Place the first one in a wealthy and supporting family. Place the second in a war zone in Africa (or in the jungle 3.000 years ago). The boy in the jungle is not likely to develop any selfawareness and self-identity based on the realization of its talent, nor will its "career" be affected (see Null hypothesis 1). Is talent then, or the environment acted upon the individual, the deciding factor? Talent may well be conceived as an external influence. One could argue that it may not be "external" in the strict sense, but what is examined here are tendencies towards an abstract archetype.

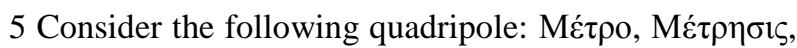

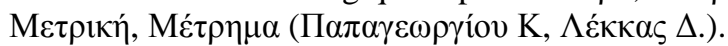


It goes without doubt that in any given task, individuals' performance will vary considerably; indeed performance will be normally distributed. It is also very likely that such performances correspond to biological adaptations which are greatly affected by genome, or brain functions -nothing new here. Saying that the performance of some individuals in the extreme right region of the Gaussian bell is indicative of talent is nothing more than a value judgment; an assumption that certain skills are conceived as important. In the end, it is a recognition not of the skills but of their value to us; then skills become pure gold (talanton).

Therefore, both cases (talent as internal or external factor), may be reducible to just one: talent as an external judgment. Talent as an idea is absolutely bound to public perception of what is a "superior" behavior, which, in turn, society decides to reward (Sandel, 2010, p. 39). Criteria change from time to time, inter-culturally and intraculturally; they even reverse. Therefore, it is more sound to treat talent as an external agent, irrespective of whether a specific physical or cognitive substrate is present or absent.

\section{Unintentional Exposure}

"Unintentional" is a non-concept. It may only be defined as lack of intention. However, in the phrase "unintentional exposure" it is not clear whether what is meant is a general lack of intention, or the existence of negative intention for someone to be exposed, or to consume certain (by-)products. In this still young field of applied ethics, the terms need to be defined. Here, unintentional exposure is treated in the former sense, as something for which the ethical subject lacks the volition to be exposed at, while she does not wish not to be exposed either.

Autonomy requires individuals to be given the opportunity to make an informed, un-coerced decision (informed consent). Beauchamp \& Childress describe the seven elements of informed consent which include three kinds of elements:

- Threshold elements, or preconditions (competence to understand and decide, voluntariness in deciding).

- Information elements (disclosure of material information, recommendation of a plan, and understanding of disclosure and recommendation).

- Consent elements (decision in favor of a plan and authorization of the chosen plan) (adapted from Beauchamp \& Childress, 2001, p. 80).

Minors are not automatically incompetent for all tasks. There appears to be a continuum of autonomy and of competency degrees (Beauchamp \& Childress, 2001, p. 72). A useful rule of thumb is for individuals bellow the age of consent to be presumed not having the decision-capacity unless shown otherwise (the opposite being the case for adults): indeed, as studies of cognitive development have shown, whereas children over the age fourteen are as capable as adults in making decisions, minors under eleven lack many capacities to make decisions (Berg, Appelbaum, Lidz, \& Parker, 2001, p. 97).

When it comes to minors, there is a clash between liberty, autonomy and incompetence. A free man is (or should be) someone who is able to make decisions. Children need some kind of support for their autonomy i.e. to temporary compromise their freedom in the short term in order to ensure autonomy in the long-term ( $c f$. best interests standard). This intervention is paternalism taken literally. Promoting autonomy of incompetent individuals (patients, minors etc.) has two sides: a negative and a positive: on one hand, the child is not allowed to take its own decisions in several matters; and this is the negative aspect. The positive one, on the other hand, is a safeguard for the ability of children to act freely later on: the parent is prohibited from deciding on behalf of the child on matters such as the deprivation of child's reproductive capacity, i.e. sterilization(Feinberg, 1986).

Obviously, the former entail several assumptions, as they are based on valuejudgments: "capacity", "interests", "freedom", "liberty", "autonomy", "temporal". Notwithstanding the chaotic implications every different definition of the said terms 
would have, the terms are used in their ordinary legal sense. This violation (i.e. not defining each term) is made under the assumption that even a loose use of these terms would not affect the conclusions.

Children are the main focus of this discussion about talent since their identity is altered (or realized?) when labelled as such. More general conversations about enhancement, liberty, justice autonomy and still other related concepts are addressed by Rawls, Nozick, Kamm, Buchanan etc. in various instances. However the purpose of this article is not that much to say something about the plethora of arguments and counterarguments, but rather to place the matter in a definite reference point; to say something about what is the relation of individuals to their (conceived as) natural abilities before any further stance is adopted. What the author wishes to see in this polarized set of arguments is a dialectic including both poles (autonomy vs heteronomy, freedom vs paternalism etc.) where a model will be articulated explaining how both poles apply in a given situation and when each pole predominates and regarding what.

What is interesting about the talentdebate, is that what is at stake is a conception about an individual being talented, not something "real", i.e., talent. At some point one can't but see that at least some individuals treated as special, become such; a selffulfilling-prophecy pattern becomes visible (Carlin, 2005; cf. pygmalion effect Rosenthal \& Jacobson, 1968).

"Simply put, when teachers expect students to do well and show intellectual growth, they do; when teachers do not have such expectations, performance and growth are not so encouraged and may in fact be discouraged in a variety of way" (Rhem, 1999).

In any case, the young child is exposed to a construct being projected upon it; one that will probably define its future life, its selfidentity whether it actually manages to live up to the expectations or not (cf. the relevant discussion regarding nature vs. society in Kamm 2013 pp. 262-263). This has considerable implications, since the discussion of talent-development regresses to enhancement and the question shifts from undertaking the cost of actualizing a potential to taking the moral responsibility to enhance individuals.

The issue here is not to distinguish between what a Kantian deontologist or an actor rule- utilitarian would say; this is too easy to predict. What is difficult is to start treating talent as an unintentional agent, which is external, and unlike other "externalities" (to borrow a term from economics), such as air pollution and fluoride in the tap-water, talent is first and foremost an idea, a social construct, a meme.

In conclusion, it has been argued that talent may be considered an unintentional agent. Taken this way discussion about talent regresses to a discussion about enhancement. When considering how to safeguard a "talented" child's autonomy, one should probably consider its future wishes as well as the development of the capacity to actualize these wishes; however care should be taken to attend to what a child would want not to do as well. When children get older, they are expected to appreciate their parents meant well; moreover we should equally expect children, as grown-ups, to equally expect their parents to have not projected their egoistic wants and plans on them (their children) even on the pretext of some talent they might have identified. Developing the capacities of a child (or even an embryo) both promotes and hinders its freedom as it simultaneously opens up certain possibilities and conceals others ( $c f$. relevant discussion in Kamm 2013 pp.257258). It is a double-edged knife However, the author hopes that by having a paradigm shift in the expertise field, if generality (erudition, broad learning) prevails over the current specialization-mania, capacities (such as imagination) that unlock, rather than limit future possibilities, will be more favourably treated. This short article will close with an unexpected question: Could the opposites of talent (e.g. mental retardation) be perceived as unintentional agents as well? 


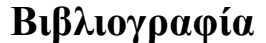

Anshel MH, Lidor R. Talent Detection Programs in Sport: The Questionable Use of Psychological Measures. Journal of Sport Behavior 2012, 35(3):239-266.

Atlan H. La fin du "tout génétique"?: vers de nouveaux paradigmes en biologie (Greek). Leader Books, 1999.

Beauchamp TL, Childress JF. Principles of Biomedical Ethics, Oxford University Press, 2001:454

Berg JW, Appelbaum PS, Lidz CW, Parker LS. Informed Consent: Legal Theory and Clinical Practice, 2nd ed., 2001:352

Brant AM, Munakata Y, Boomsma DI, Defries JC, Haworth CMA, Keller MC, Hewitt JK. The Nature and Nurture of High IQ: An Extended Sensitive Period for Intellectual Development. Psychological Science 2013, 24(8):1487-95.

Butko NJ, Movellan JR. Learning to Learn. In 2007 IEEE 6th International Conference on Development and Learning, 2007:151-156.

Carlin F. The Grandmaster Experiment Psychology Today, 2005. Retrieved September 04, 2013, from http://www.psychologytoday.com/articles/20 0506/the-grandmaster-experiment.

Chabris CF, Hebert BM, Benjamin DJ, Beauchamp J, Cesarini D, van der Loos M, Laibson D. Most reported genetic associations with general intelligence are probably false positives. Psychological Science 2012, 23(11):1314-23.

Cote J, Baker J, Abernathy B. Practice and Play in the Development of Sport Expertise. In: Eklund R, Tenenbaum G (Ed). Handbook of sport psychology, Hoboken NJ, 3rd ed., 2007:184-202.

Csikszentmihalyi M. Flow: The psychology of optimal experience. Praha: Lidové Noviny, 1990. Retrieved from http://www.vedpuriswar.org/book_review/Fl ow.doc.

Dai DY. Essential Tensions Surrounding the Concept of Giftedness. In L. Shavinina (Ed.), International handbook on giftedness, Springer, 2009:39-80.
Davis GA. New Developments in Gifted Education. In L. V. Shavinina (Ed.), International Handbook on Giftedness, Springer, 2009:1035-1044.

Durand-Bush N, Salmela JH. The development of talent in sport. In: Singer RN, Hausenblas HA, Janelle C (Ed). Handbook of sport psychology, New York: Wiley, 2001:269289.

Dweck CS, Leggett EL. A social-cognitive approach to motivation and personality. Psychological Review 1988, 95(2):256-273.

Ericsson KA. The Influence of Experience and Deliberate Practice on the Development of Superior Expert Performance. In: Ericsson K, Charness N, Feltovich PJ, Hoffman RR (Ed.). The Cambridge handbook of expertise and expert performance, 2006:683-704.

Ericsson KA. Deliberate practice and the modifiability of body and mind: Toward a science of the structure and acquisition of expert and elite performance. International Journal of Sport Psychology 2007, 38:4-34.

Ericsson KA. Training history, deliberate practice and elite sports performance: an analysis in response to Tucker and Collins review--what makes champions? British Journal of Sports Medicine 2012, 47(9):533-5.

Ericsson KA, Kintsch W. Long-term working memory. Psychological Review 1995, 102(2):211-45. Retrieved from http://www.ncbi.nlm.nih.gov/pubmed/22306 890.

Ericsson KA, Krampe R, Tesch-Römer C. The role of deliberate practice in the acquisition of expert performance. Psychological Review 1993, 100(3):363-406. Retrieved from http://doi.apa.org/psycinfo/1993-40718-001.

Ericsson KA, Nandagopal K, Roring RW. An Expert Performance Approach to the Study of Giftedness. In: L. Shavinina (Ed.), International handbook on giftedness, Springer, 2009a:129-154.

Ericsson KA, Nandagopal K., Roring RW. Toward a science of exceptional achievement: attaining superior performance through deliberate practice. Annals of the 
New York Academy of Sciences 2009b, 1172:199-217.

Feinberg J. Harm to Self Arizona, Tucson: Oxford University Press, 1986:448.

Flynn JR. The mean IQ of Americans: Massive gains 1932 to 1978. Psychological Bulletin 1984, 95:29-51.

Fraser-Thomas J. Community size in youth sport settings: Examining developmental assets and sport withdrawal. Revue phénEPS/PHEnex Journal 2010, 2(2):1-9.

Gagne F. Debating Giftedness: Pronat vs. Antinat. In: Shavinina L. (Ed.), International handbook on giftedness, Springer, 2009:155204.

Galton SF. Hereditary genius. London: MacMillan and co. And New York:1869.

Geake JG. Neuropsychological Characteristics of Academic and Creative Giftedness. In: L. Shavinina (Ed.), International handbook on giftedness, Springer, 2009:261-274

Goleman D. Emotional Intelligence: Why It Can Matter More Than IQ, 1995.

Gottfried AE, Gottfried AW. Development of Gifted Motivation: Longitudinal Research and Applications. In: L. Shavinina (Ed.), International handbook on giftedness, 2009:617-632.

Gross MUM. Highly Gifted Young People: Development from Childhood to Adulthood. In L. Shavinina (Ed.), International handbook on giftedness, Springer, 2009:337-352.

Haier R. What Does a Smart Brain Look Like? Scientific American Mind, 2009:26-33.

Haier RJ, Jung RE, Yeo R., Head K, Alkire MT. Structural brain variation and general intelligence. NeuroImage 2004, 23(1):42533.

Helgadóttir FD, Menzies RG, Einstein D. Magical thinking and obsessive-compulsive symptoms in Australia and Iceland: A crosscultural comparison. Journal of ObsessiveCompulsive and Related Disorders 2012, 1(3):216-219.

Howe MJA, Davidson JW, Sloboda JA. Innate Talents: Reality Or Myth. Behavioural and Brain Sciences. Behavioural and Brain Sciences, 1998, 21:399-442.
Hu Y, Ericsson KA, Yang D, Lu C. Superior selfpaced memorization of digits in spite of a normal digit span: the structure of a memorist's skill. Journal of Experimental Psychology. Learning, Memory, and Cognition 2009, 35(6):1426-42.

Hunt E. Expertise, Talent, and Social Encouragement. In: Ericsson K, Charness N, Feltovich PJ, Hoffman RR (Ed.). The Cambridge handbook of expertise and expert performance, Cambridge University Press, 2006:31-40.

Jensen AR. Speed of information processing in a calculating prodigy. Intelligence, 1990, 14(3):259-274.

Kamm FM. Bioethical Prescriptions: To Create, End, Choose, and Improve Lives, OUP USA, 2013.

Klissouras V. Heritability of adaptive variation. Journal of Applied Physiology 1971, (31):338-344.

Klissouras V, Casini B, Di Salvo V, Faina M, Marini, C, Pigozzi F, Parisi P. Genes and olympic performance: a co-twin study. International Journal of Sports Medicine 2001, 22(4):250-5.

Kono T. Nuclear transfer and reprogramming. Reviews of Reproduction 1997, 2(2):74-80.

Lekkas D. Towards an epistemonic theoretical surveillance of dance. In: Surveillance of Greek Music \& Dance. Greek Open University, 2003:204-206

Lewontin R. It ain't necessarily so: The dream of the human genome and other illusions. New York: New York Review Books, 2001.

Lewontin R. It's Even Less in Your Genes. The New York Review of Books, 2011. Retrieved July $\quad 15, \quad 2013, \quad$ from http://www.nybooks.com/articles/archives/20 11/may/26/its-even-less-yourgenes/?pagination=false.

Locurto CM. Sense and nonsense about IQ: the case for uniqueness. Praeger, 1991.

Lubinski D, Benbow C, Webb R, Bleske-Reckek A. Tracking exceptional human capital over two decades. Psychological Science 2006, 17(3):194-199.

Maguire E, Valentine E, Wilding J, Kapur N. Routes to remembering: the brains behind 
superior memory. Nature Neuroscience 2002, 6(1):90-5.

O'Brien R (n.d.). History of Diving. Retrieved July 16, 2013, from http://www.usadiving.org/about/diving101/history-of-diving.

Papageorgiou KG. Magical Thinking | e-book, 2010 . http://www.creationray.com/mybooks/thinking-book/.

Papageorgiou KG. Talents \& Gifted Education: A report on research findings and current status, Athens, 2014:112. Retrieved from http://www.creationray.com/wpcontent/uploads/2014/11/ReportBioethics201 41.pdf.

Pfeiffer SI. The gifted: clinical challenges for child psychiatry. Journal of the American Academy of Child and Adolescent Psychiatry 2009, 48(8):787-90.

Plomin R, Haworth C. Common DNA markers can account for more than half of the genetic influence on cognitive abilities. Psychological Science 2013, 24(4) :562-8.

Rattan A, Good C, Dweck CS. "It's ok - Not everyone can be good at math": Instructors with an entity theory comfort (and demotivate) students. Journal of Experimental Social Psychology 2012, 48(3):731-737.

Rhem J. Pygmalion In: The Classroom. The National Teaching \& Learning Forum, 1999, $8(2): 1$.

Rosenthal R, Jacobson L. Pygmalion in the classroom. New York: Holt, Rinehart \& Winston, 1968.

Rossum van JHA. Giftedness and Talent in Sport. In: L. Shavinina (Ed.), International handbook on giftedness 2009, Springer:751792.

Sandel M. Justice: What's the right thing to do?. New York: Farrar, Straus and Giroux, 2010.

Schmidt RA, Wrisberg CA. Motor Learning and Performance: A Situation-based Learning Approach. (I. Champaign, Ed.). Human Kinetics, 2008.

Sekowski A, Siekanska M, Klinkosz W. On Individual Differences in Giftedness. In: L. Shavinina (Ed.), International handbook on giftedness, Springer, 2009:467-486.
Shavinina LV. A Unique Type of Representation is the Essence of Giftedness: Towards a Cognitive-Developmental Theory. In: Shavinina L. (Ed.). International handbook on giftedness, Springer, 2009: 231-259.

Simonton D. Origins of genius: Darwinian perspectives on creativity. Oxford New York: Oxford University Press, 1999. Retrieved from http://doi.apa.org/psycinfo/1999-02789000 .

Simonton DK. Greatness: Who Makes History and why, 1994.

Simonton DK. Creative productivity: A predictive and explanatory model of career trajectories and landmarks. Psychological Review 1997, 104(1):66-89.

Simonton DK. Creativity as Blind Variation and Selective Retention: Is the Creative Process Darwinian? Psychological Inquiry 2000, 10(4):309-328.

Sternberg R. Beyond g: The theory of successful intelligence. In S. RG \& G. EL (Eds.), The general factor of intelligence: How general is it. Mahwah, NJ: Lawrence Erlbaum Associates, 2002.

Terman LM. Genetic Studies Of Genius Volume I Mental And Physical Traits of a Thousand Gifted Children (2nd ed.). California: Stanford University Press, 1926.

Vrecko S. Just How Cognitive Is "Cognitive Enhancement"? On the Significance of Emotions in University Students' Experiences with Study Drugs. AJOB Neuroscience 2013, 4(1):4-12.

WADA (n.d.). Gene Doping. Retrieved September 18, 2013, from http://www.wadaama.org/en/Science-Medicine/Sciencetopics/Gene-Doping/.

Wallace B, Maker CJ. Discover/Tasc: An Approach to Teaching and Learning That Is Inclusive Yet Maximises Opportunities for Differentiation According to Pupils' Needs. In: Shavinina L (Ed.). International handbook on giftedness, Springer, 2009:1113-1142.

Wikipedia (n.d.). Charles Servizio. Retrieved July 15, 2013, from http://en.wikipedia.org/wiki/Charles_Servizio

Dickens WT, Flynn JR, Crawford C, Fisher MA, Hanson R, Harris J. Heritability estimates 
versus large environmental effects: The IQ paradox resolved. Psychological Review 2001, 108:346-369.

Wilmore JH, Costill DK. Physiology of sport an exercise. Human Kinetics, 3rd ed., 2004.

Wilson C. A Criminal History of Mankind. Granada Publ., 1984

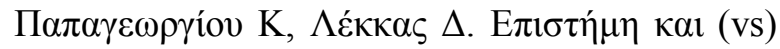

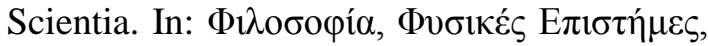

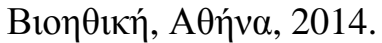

